\title{
Hour Times Microgram Per Milliliter Per Milligram Per Kilogram Per Day
}

National Cancer Institute

\section{Source}

National Cancer Institute. Hour Times Microgram Per Milliliter Per Milligram Per Kilogram

Per Day. NCl Thesaurus. Code C105467.

A dose calculation unit expressed in hours times micrograms per milliliter, divided by

milligram per kilogram per day. 